\title{
PENERAPAN METODE HOT FIT DALAM EVALUASI SISTEM INFORMASI MANAJEMEN RUMAH SAKIT DI RSUD JOMBANG
}

\author{
Chandra Sukma ${ }^{1}$, Indra Budi ${ }^{2}$ \\ ${ }^{1}$ Dosen Sistem Informasi, Universitas Pesantren Tinggi Darul Ulum (Unipdu) Jombang \\ ${ }^{1}$ E-mail: chandrasukma@ft.unipdu.ac.id \\ ${ }^{2}$ Dosen Fakultas Ilmu Komputer, Universitas Indonesia Kampus UI Depok \\ ${ }^{2}$ E-mail : indra@cs,ui.ac.id
}

\begin{abstract}
ABSTRAK
Sistem Informasi Rumah Sakit (SIMRS) merupakan aplikasi berbasis komputerisasi yang dikembangkan untuk manajemen data rekam medis. Penerapan SIMRS di RSUD Kabupaten Jombang masih ditemukan kendala antara lain terdapat user yang kesulitan menggunakan SIMRS, pemahaman yang kurang tentang SIMRS, sumber daya yang terbatas, kurangnya dukungan pimpinan, serta penggunaan SIMRS yang belum memanfaatkan data terpusat.

Tujuan penelitian ini untuk menggamba kan faktor-faktor yang berpengaruh terhadap efektivitas penerapan SIMRS dengan menggunakan model evaluasi Human-OrganizationTechnology (HOT) Fit. Jenis penelitian yng digunakan adalah pendekatan kuantitatif. Populasi penelitian ini adalah pengguna (user) aplikasi SIMRS di RSUD kabupaten Jombang, dengan sampel yaitu total populasi sebanyak 64 orang. Hasil penelitian dengan korelasi menunjukkan ada hubungan ketersediaan fasilitas dan kualitas informasi dengan efektivitas penerapan SIMRS dan tidak ada hubungan kapabilitas personal, efektivitas pelatihan, dukungan manajemen puncak, dukungan rekan kerja, dan kualitas sistem dengan efektivitas penerapan SIMRS.

Hasil penelitian dengan analisis regresi linier sederhana menunjukkan ada pengaruh ketersediaan fasilitas terhadap efektivitas penerapan SIMRS sebesar 33,5\%. Saran yang diberikan yaitu pengkajian ulang terhadap rancangan aplikasi SIMRS, monitoring dan evaluasi terkait ketersediaan sumber daya manusia dan fasilitas di RSUD Jombang, feedback dari user terkait dengan aplikasi SIMRS, dan pengoptimalan dukungan manajemen puncak dalam evaluasi penerapan SIMRS.
\end{abstract}

Kata kunci: hot fit model, Sistem Informasi Rumah Sakit

\section{ABSTRACT}

Hospital Information System (SIMRS) is a computerized application developed for medical record data management. Implementation of SIMRS in RSUD Jombang still found obstacles among others there are users who have difficulty using SIMRS, lack of understanding about SIMRS, limited resources, lack of leadership support, and the use of SIMRS that have not utilized centralized data.

The purpose of this study is to draw on factors that influence the effectiveness of SIMRS implementation by using the Human-Organization-Technology (FT) evaluation model. Type of research yng used is quantitative approach. The population of this study is the user (user) SIMRS application in RSUD Jombang district, with a sample of total population of 64 people. The results of the correlation study indicate that there is a relationship between the availability of facilities and the quality of information with the effectiveness of SIMRS implementation and no personal capability relationship, training effectiveness, top management support, peer support, and system quality with effective SIMRS implementation.

The result of the research with simple linear regression analysis shows that there is influence of facility availability to the effectiveness of SIMRS implementation by 33,5\%. Suggestion given is review of SIMRS application design, monitoring and evaluation related to availability of human resources and facilities at RSUD Jombang, user feedback related to SIMRS application, and optimization of top management support in evaluation of SIMRS implementation Keywords: hot fit model, Hospital Information System 


\section{PENDAHULUAN}

Rumah sakit sebagai suatu lembaga yang menyediakan layanan kesehatan bagi masyarakat, dalam pengelolaannya terdapat banyak data dan informasi yang mengalir selama proses pelayanannya. Untuk memastikan bahwa data dapat diolah dengan baik sehingga menghasilkan informasi yang berguna, tepat dan akurat serta dapat diakses oleh semua pihak yang terlibat dalam penyediaan layanan kesehatan yang baik, dibutuhkan bantuan infrastruktur teknologi informasi dan komunikasi yang dikenal dengan sistem informasi rumah sakit. Berdasarkan peraturan Menteri Kesehatan Republik Indonesia nomor 1171 / MENKES / PER/ VI / 2011 yang menyebutkan bahwa "setiap rumah sakit wajib melaksanakan Sistem Informasi Rumah Sakit" maka rumah sakit yang ada di indonesia mulai menerapkan sistem untuk meningkatkan pelayanan. SIMRS adalah suatu sistem terkomputerisasi yang mampu melakukan pengolahan data secara cepat, akurat, dan menghasilkan sekumpulan informasi yang saling berinteraksi untuk diberikan kepada semua tingkatan manajemen di rumah sakit

Sistem Informasi Manajemen Rumah Sakit adalah sebuah sistem yang memproses dan mengintegrasikan seluruh alur proses manajemen layanan kesehatan dalam bentuk jaringan koordinasi, pelaporan dan prosedur administrasi untuk memperoleh informasi secara cepat, tepat dan akurat. Saat ini Sistem Informasi Manajemen SIM pada rumah sakit SIMRS merupakan sarana pendukung yang sangat penting, bahkan bisa dikatakan mutlak untuk mendukung pengelolaan operasional rumah sakit. Kebutuhan akan kecepatan layanan di instansi/perusahaan membuat peranan jaringan komputer sangat diperlukan. Dengan jaringan komputer, aliran data menjadi lebih cepat, terintegrasi, dan mudah diawasi (Arifin, 2011). Selain aliran data masih banyak hal-hal yang kurang diperhatikan lainnya, semisal sebuah topologi jaringan apa yang cocok untuk diterapkan dan diimplementasikan untuk menjebatani jaringan tersebut (Arifin, 2011).

Beberapa Rumah Sakit telah menerapkan SIMRS tetapi dalam implementasi tersebut, tidak sedikit yang mengalami kegagalan dan ada juga yang bisa dikatakan berhasil. Khususnya penerapan Sistem Informasi Manajemen Rumah Sakit SIMRS di RS RSUD Jombang ini pada awalnya mengalami banyak kendala diantara ada yang mendukung dan tidak mendukung penerapan sistem informasi. mereka menganggap keberadaan sistem akan menambah pekerjaan. untuk mengatasi hal tersebut maka pihak manajemen mencoba unuk melakukan pendekatan dan pelatihan karena keberhasilan implementasi SIMRS akan bergantung pada pengguna SIMRS, Walaupun pelaksanaan sistem tersebut masih baru, namun penggunaan sistem ini masih memiliki banyak kendala dan hambatan. SIMRS yang ada telah terintegrasi akan tetapi masih belum maksimal ada uni unit tertentu yang memiliki Sistem Informasi Sendiri. Selain itu pengguna yang merasa kesulitan dalam hal penggunaan sistem, membuat pelaksanaan sistem ini menjadi terhambat. Kesulitan pengguna dalam menggunakan sistem informasi akan memberikan dampak kepada ketidakberhasilan penerapan SIMRS, yang akan berpengaruh terhadap pelayanan rumah sakit kepada pasien. Berdasarkan hasil akreditasi yang dilaksanapakn pada tahun 2014 RSUD Jombang di dapatkan hasil bahwa evaluasi penerapan SIMS menjadi catatan bagi pihak rumah sakit.

Sejak RSUD Jombang menjadi mitra BPJS beban kerja SDM di RSUD Jombang menjadi semakin tinggi, dan diperlukan dukungan sistem informasi yang cukup efisien untuk membuat pekerjaan menjadi lebih mudah. Mulai dari unit pendaftaran yang melakukan input data, proses pengkodingan menggunakan INA-CBG's sampai dengan klaim verifikasi ke BPJS mutlak 
didukung oleh suatu sistem informasi yang baik pula. Dalam hal pelayanan pada pasien-pasien BPJS ini,sistem informasi yang digunakan adalah sistem informasi yang menggunakan software dari BPJS, tetapi diperlukan sosialisasi dengan pelatihan khusus untuk karyawan yang menggunakan langsung sistem informasi tersebut. Beberapa hal yang sering dikeluhkan oleh pengguna langsung SIMRS adalah komputer yang mendadak tidak bisa difungsikan, proses loading yang memakan waktu lama,sampai dengan terlalu banyak kolom dalam inputan data yang harus dilengkapi dan akhirnya lebih banyak dilewatkan atau tidak diisi. Bagi pihak manajemen sebagai pengguna tidak langsung SIMRS,terutama bagian keuangan,mengeluhkan masih terdapat temuan resources yang tidak terbayar karena luput diinput pada sistem yang akhirnya berdampak kerugian materiil bagi rumah sakit. Belum lagi karena SIMRS belum mendukung kegiatan back office,pihak penentu kebijakan dalam hal ini adalah jajaran direksi,tidak mendapatkan reportbulanan yang dapat melihat dan mengukur kinerja pelayanan pada masing-masing unit. Perlu dilakukan evaluasi SIMRS agar dalam pengembangan kedepan pihak RSUD mampu memenuhi standart ISO sehingga bisa menaikan akreditasi

\section{METODE PENELITIAN}

Penelitin ini menggunakan metode Hot-fit Model karna pada saat studi pendahuluan di dapatkan kendala pada komponen manusia, organisasi. Berdasarkan hal tersebut maka sebelum dilakukan pengembangan SIMRS selanjutnya, diperlukan suatu analisis untuk mengidentifikasi tingkat penerimaan pengguna terhadap sistem dan bagaimana hasil analisis terhadap penerapan SIMRS yang dijalankan saat ini. Analisis ini nantinya akan berusaha mengetahui faktor-faktor yang mendukung keberhasilan penerapan dari SIMRS, sehingga kegunaan dan keberlanjutan sistem dapat dimanfaatkan semaksimal mungkin untuk mendukung pelayanan kesehatan kepada masyarakat. Analisis didalam penelitian ini menggunakan metode penerapan kerangka kerja HOT Fit Model merupakan salah satu kerangka teori yang digunakan untuk evaluasi sistem informasi dalam bidang pelayanan kesehatan.

Teori HOT-Fit ditujukan pada komponen inti dalam sistem informasi yaitu Human (Manusia) - Organization (Organisasi) - Technology (Teknologi) dan kecocokan diantara ketiga komponen tersebut. Selain itu Brender et al., (2006) juga menyebutkan bahwa keberhasilan suatu implementasi sistem informasi juga dapat diidentifikasi melalui persepsi para pengguna. Pengguna sistem informasi atau end user meliputi operator billing system yang langsung mengoperasiksan sistem dan juga pihak manajemen yang merupakan pengguna dari hasil atau output dari billing system. Menurut Brigl et al., (2005) evaluasi sistem informasi rumah sakit perlu dilakukan untuk melihat sejauh mana kualitas outcome memberikan kontribusi untuk rumah sakit. Hasil evaluasi dapat digunakan sebagai acuan untuk memperbaiki atau menyempurnakan SIMRS dan meminimalkan potensi masalah yang masih ada,sehingga SIMRS menjadi lebih baik,sempurna serta dapat mendukung visi, misi dan tujuan organisasi.

Jenis penelitian ini adalah deskriptif dengan pendekatan kuantitatif. Variabel yang diteliti adalah faktor manusia (sikap pengguna sistem), organisasi (struktur dan lingkungan organisasi), teknologi (kualitas informasi) dalam kinerja Sistem Informai Manajemen Rumah Sakit di RSUD kabupaten Jombang. Populasi dan sampel dalam penelitian ini adalah seluruh petugas yang berkaitan langsung dengan SIMRS yang berjumlah 63 orang. Instrumen dalam penelitian ini adalah kuesioner, lembar observasi dan pedoman wawancara. Analisis data dilakukan secara analisis diskriptif. Sehingga dapat di jelaskan dengan kerangka konsep sebagai berikut : 


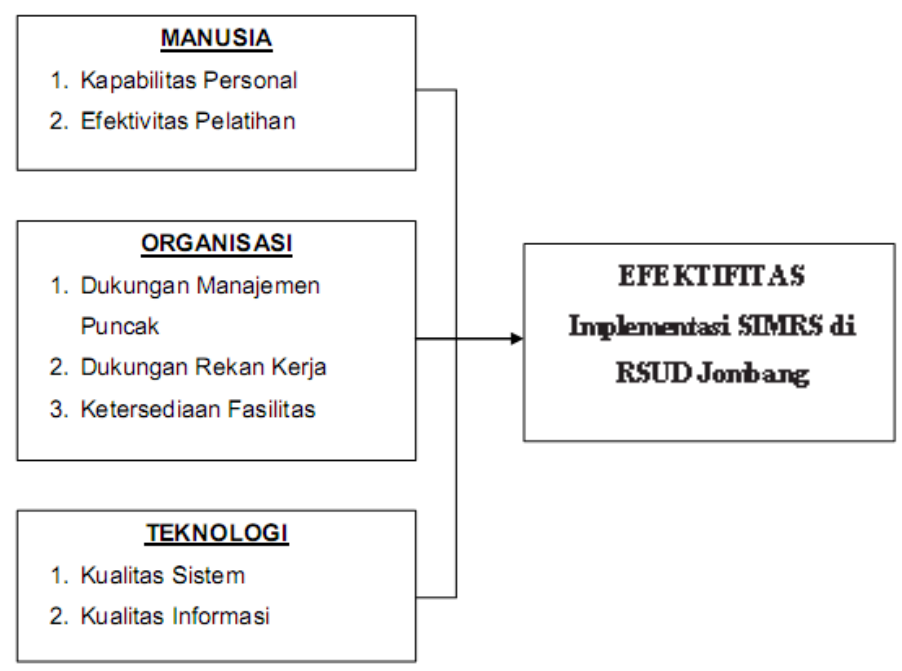

Gambar 1 Kerangka Konsep

Teknik pengumpulan data adalah cara-cara yang dilakukan untuk mengumpulkan data dan keteranganketerangan lainnya dalam penelitian yang akan dilakukan. Dalam penelitian ini penulis mengumpulkan data dengan cara Penelitian Lapangan (field research) Yaitu dengan melakukan penelitian pada perusahaan dengan tujuan memperoleh data primer dan penelitian ini dilaksanakan dengan cara pengumpulan data melalui Kuisioner, yaitu mengajukan beberapa pertanyaan yang berhubungan dengan masalah yang akan diteliti, kemudian hasilnya diuji dengan kriteria yang telah ditetapkan. Variabel yang diteliti adalah faktor manusia (sikap pengguna sistem), organisasi (struktur dan lingkungan organisasi), teknologi (kualitas informasi) dalam kinerja Sistem Informai Manajemen Rumah Sakit di RSUD kabupaten Jombang. Populasi dan sampel dalam penelitian ini adalah seluruh petugas yang berkaitan langsung dengan SIMRS yang berjumlah 63 orang dan dipilih sample 30 orang dengan metode random sampling. Instrumen dalam penelitian ini adalah kuesioner, lembar observasi dan pedoman wawancara. Analisis data dilakukan secara analisis diskriptif.

Tabel 1 Jumlah subyek penelitian (operator SIMRS)

\begin{tabular}{|c|c|c|c|}
\hline No. & Unit Pelayanan & Nama Ruang & Subyek \\
\hline \multirow{9}{*}{1.} & \multirow{8}{*}{ Rawat Jalan } & Poli Rawat Jalan & 17 orang operator \\
\hline & & Laboratorium IRD & 2 orang operator \\
\hline & & Apotik IRD & 2 orang operator \\
\hline & & Kasir IRD & 2 orang operator \\
\hline & & Hemodialisa & 1 orang operator \\
\hline & & IRD & 1 orang operator \\
\hline & & Pendaftaran Rawat Jalan & 4 orang operator \\
\hline & & Kasir Rawat Jalan & 1 orang operator \\
\hline & & Paviliun & 13 orang operator \\
\hline
\end{tabular}




\begin{tabular}{|r|l|l|l|}
\hline 2. & Rawat Inap & Ponek & 1 orang operator \\
\hline \multirow{3}{*}{3} & \multirow{3}{*}{ Penunjang } & Farmasi & 11 orang operator \\
\cline { 3 - 4 } & & Laboratorium Patologi Klinik & 2 orang operator \\
\cline { 3 - 4 } & Laboratorium Anatomi & 1 orang operator \\
\cline { 3 - 4 } & Kasir & 5 orang operator \\
\hline \multicolumn{2}{|c}{ Jumlah } & $\mathbf{6 3}$ or ang operator \\
\hline
\end{tabular}

Untuk mendapatkan hasil penelitian yang baik dan dapat dipertanggung jawabkan, diperlukan serangkaian pengujian baik terhadap instrumen kuisioner hubungan antar variabel maupun hipotesis yang diajukan. Dalam proses perhitungannya, penulis menggunakan alat bantu SPSS. Adapun metode analisis statistik yang digunakan dalam penelitian ini adalah sebagai berikut:

1. Uji validitas digunakan untuk mengetahui kelayakan butir-butir pertanyaan (instrumen) dalam mendefiniskan suatu varibel. Uji validitas di dalam PLS dinilai dengan melihat convergent validity masingmasing indikator. Convergent validity dapat dievaluasi dalam tiga tahap yaitu indikator validitas, reliabilitas konstruk dan nilai average variance extracted (AVE). Indikator validitas dapat dilihat dari nilai loading factor. Loading factor adalah korelasi antara indikator tersebut dengan konstruknya. Semakin tinggi korelasinya, semakin tinggi validitasnya. Bila nilai loading factor suatu indikator lebih dari 0,5 dan nilai t-statistic lebih dari 2,0 maka dikatakan valid. Jika sebaliknya, nilai loading factor kurang dari 0,5 dan t-statistic kurang dari 2,0, maka dikeluarkan dari model8. Sedangkan uji reabilitas dilakukan pada masing-masing variabel, sehingga dapat diketahui konstruk variabel mana yang tidak reliable. Reabilitas suatu konstruk variabel dikatakan baik jika memiliki nilai Cronbach Alpha $>0,60$ dan composite reliability $>0,70$

2. Setelah uji validitas dan realibilitas, langkah selanjutnya yaitu melakukan uji-t serta signifikansi dari koefisien parameter jalur struktural. Pada penelitian ini, ditetapkan bahwa nilai signifikansi $=5 \%=0,05$ dengan degree of freedom (derajat kebebasan) $\mathrm{df}=(\mathrm{n}-$ $m-1)$, dengan $n$ sama dengan jumlah responden. Variabel dikatakan signifikan apabila nilai T-statistics lebih besar dari nilai T-table (T-statistics $>\mathrm{T}$ table)

3. Pengujian hipotesis dilakukan dengan melihat besarnya nilai $\mathrm{T}$-statistics yang menggunakan tigkat signifikansi sebesar 95\% $(\alpha=0.05)$. Nilai T-table dengan tingkat siginifikasi $95 \%$ adalah 1,96. Batas untuk menolak dan menerima hipotesis yang diajukan mengacu pada nilai 1.96 , dimana apabila nilai Ttable berada pada rentang nilai -1.96 dan 1.96 , maka hipotesis akan ditolak atau dengan kata lain menerima hipotesis nol (H0)

\section{HASIL DAN PEMBAHASAN}

Pada penelitian ini menggunakan dua analisis yaitu analisis Unvarian berfungsi untuk meringkas hasil pengukuran data sehingga kumpulan data tersebut berubah menjadi informasi yang berguna. Analisa univariat dilakukan pada setiap variabel yang diteliti. Kemudian dilanjutkan dengan Analisis Bivariat untuk menguji ada atau tidaknya pengaruh antara variabel dependen dan independen

\subsection{Analisis Unvarians}

Analisis univariat bertujuan untuk mendeskripsikan semua variabel penelitian. Selain untuk melihat distribusi frekuensi, analisis univariat dalam penelitian ini juga melihat capaian skor semua variabel penelitian. Berikut rekapitulasi hasil indeks capaian skor masing - masing variabel. 
Tabel 2 Rekapitulasi Indeks Capaian Skor Variabel Penelitian

\begin{tabular}{|l|c|}
\hline Variabel Penelitian & Indeks capaian Skor (\%) \\
\hline Kapabilitas Personal & 73,78 \\
\hline Efektivitas Pelatihan & 67,95 \\
\hline Dukungan Manajemen Puncak & 65,05 \\
\hline Dukungan Rekan Kerja & 60,98 \\
\hline Ketersediaan Fasilitas & 67,84 \\
\hline Kualitas Sistem & 66,10 \\
\hline Kualitas Informasi & 67,91 \\
\hline Efektivitas Penerapan SIMRS & 66,89 \\
\hline
\end{tabular}

Dapat diketahui bahwa indeks capaian skor tertinggi adalah variable kapabilitas personal, sedangkan indeks capaian skor paling rendah yaitu variabel dukungan rekan kerja. Ini menunjukan bahwa komponen kapabilitas personal memiliki penilaian yang lebih baik dibandingkan semua variabel dala penelitian ini.

\subsection{Analisis Bivariat}

Analisis bivariat dalam penelitian ini bertujuan untuk mengetahui faktor faktor yang mempengaruhi efektivitas penerapan aplikasi SIMRS. Analisis ini terdiri dari dua uji yaitu uji korelasi dan uji regresi linier sederhana Hasil pengujian sebagai berikut :

\section{Uji Korelasi}

Berdasarkan hasil uji korelasi diperoleh tingkat signifikansi yang berbeda beda untuk koefisien korelasi. Berikut rekapitulasi hasil uji korelasi

Tabel 3 Rekapitulasi Hasil Koefisien Korelasi

\begin{tabular}{|l|c|}
\hline Variabel Penelitian & Indeks capaian Skor $(\boldsymbol{\%})$ \\
\hline Kapabilitas Personal & 73,78 \\
\hline Efektivitas Pelatihan & 67,95 \\
\hline Dukungan Manajemen Puncak & 65,05 \\
\hline Dukungan Rekan Kerja & 60,98 \\
\hline Ketersediaan Fasilitas & 67,84 \\
\hline Kualitas Sistem & 66,10 \\
\hline Kualitas Informasi & 67,91 \\
\hline Efektivitas Penerapan SIMRS & 66,89 \\
\hline
\end{tabular}

Dari hasil rekapitulasi hasil tersebut disimpulkan bahwa variabel ketersediaan fasilitas dan kualitas informasi memiliki hubungan yang signifikan dengan efektivitas penerapan aplikasi SIMRS. Namun variabel kapabilitas personal, efektivitas pelatihan, dukungan manajemen puncak, dukungan rekan kerja, dan kualitas sistem, tidak memiliki hubungan yang siginifikan dengan efektivitas penerapan aplikasi SIMRS. Seluruh variabel bebas yang memiliki hubungan signifikan dengan variabel terikat memiliki arah hubungan yang positif langkah selanjutnya adalah melakukan uji regresi linier sederhana. 
2. Uji Regresi Linier Sederhana

Berdasarkan hasil uji regresi linier sederhana, diperoleh tingkat signifikansi

\begin{tabular}{|c|c|c|c|c|c|}
\hline Variabel Bebas & $\begin{array}{l}\text { Variabel } \\
\text { Terikat }\end{array}$ & $\begin{array}{c}\text { Koefisien } \\
\text { Regresi }\end{array}$ & $\begin{array}{c}\text { Nilai } \\
t\end{array}$ & $\begin{array}{l}\text { Nilai } \\
\text { sig }\end{array}$ & Interpretasi \\
\hline $\begin{array}{l}\text { Ketersediaan } \\
\text { Fasilitas }\end{array}$ & $\begin{array}{l}\text { Efektivitas } \\
\text { Penerapan }\end{array}$ & 0,381 & 4,203 & 0,000 & Ada pengaruh \\
\hline $\begin{array}{l}\text { Kualitas } \\
\text { Informasi }\end{array}$ & $\begin{array}{l}\text { Aplikasi } \\
\text { SIMRS }\end{array}$ & 0,276 & 0,161 & 0,095 & $\begin{array}{l}\text { Tidak ada } \\
\text { pengaruh }\end{array}$ \\
\hline
\end{tabular}

Berdasrkan rekapitulasi hasil koefisien regresi, maka dapat disimpulkan bahwa hanya variabel ketersediaan fasilitas yang memiliki pengaruh signifikan dengan efektivitas penerapan aplikasi SIMRS (nilai sig < 0,05). Sedangkan variabel kualitas informasi tidak memilikii pengaruh yang signifikan dengan efektivitas penerapan aplikasi SIMRS (nilai sig > 0,05).Nilai R2 variabel ketersediaan fasilitas yaitu 0,335 . Ini berarti sebesar $33,5 \%$ variasi nilai variabel terikat dipengaruhi oleh variabel ketersediaan fasilitas, sisanya sebesar $66,5 \%$ dipengaruhi oleh variabel lain yang tidak diketahui. Berikut adalah persamaan regresi untuk variabel ketersediaan fasilitas.

\section{KESIMPULAN}

Indeks capaian skor masing - masing variabel yaitu $73,78 \%$ pada variabel kapabilitas personal, 67,95\% pada variabel efektivitas pelatihan, $65,03 \%$ pada variabel dukungan manajemen puncak, $60,98 \%$ pada

\section{DAFTAR PUSTAKA}

Ray J. Paul, 2014, Towards a Framework for Health Information Systems Evaluation, international journal of medical informatics, Elsevier, UK

Maryati Mohd. Yusof, 2014, An evaluation framework for Health Information Systems: human, organization and technology-fit factors (HOT-fit), international journal of medical informatics, Elsevier, UK yang berbeda-beda untuk koefisien regresi. Berikut rekapitulasi hasil koefisien regresi. 
Metode Hot-Fit, Magister Teknik Informatika, Universitas Islam Indonesia

Yung, Y.F., \& Bentler, P.M. (1996). Bootstrapping techniques in analysis of mean and covariance structures. In G.A. Marcoulides \& R.E. Schumacker (Eds.), Advanced structural equation modeling: Issues and techniques (195-226). Mahwah, NJ: Erlbaum.

Chang, C., Chen, S., \& Lan, Y. (2012). Motivating medical information system performance by system quality, service quality, and job satisfaction for evidence-based practice. BMC Medical Informatics and Decision Making, 12(135)

Van Der Meidjen, M. J., Tange, H.J., Troost, J.,Hasman, A., "Determinants of Success of Inpatient Clinical Information Systems: A Literature Review," Journal of the American Medical Association, 10, 2003, 235243

Whitten, J.L., Betley, L.D.,Dittman K.C., 2004. Metode Desain dan Analisis Sistem.Edisi 6., Penerbit Andi.Yogyakarta.

Mulyanto A, 2009 Sistem Informasi Konsep \& Aplikasi, Pustaka Pelajar, Yogyakarta

Nugroho, Eko. 2008. Sistem Informasi Manajemen : Konsep, Aplikasi dan Perkembangannya. Andi. Yogyakarta Whitten, J.L., Betley, L.D.,Dittman K.C., 2004. Metode Desain dan Analisis Sistem. Edisi 6., Penerbit Andi.Yogyakarta. 
